\title{
ASPEKTE VAN POPULÊRE OPVATTINGE OOR DIAREESIEKTES ONDER TSWANASPREKENDE STEDELINGE
}

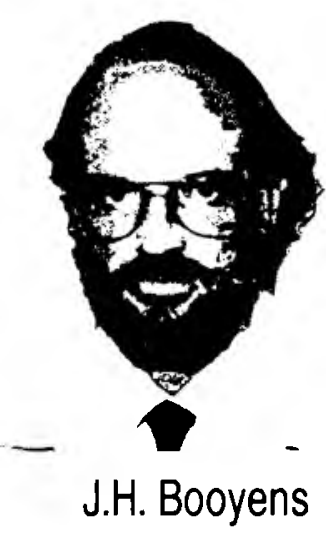

\section{Abstract}

This article contains a general overview of cultural perceptions of diarrhoeal disease amongst infants as expressed by Tswanaspeaking urbanites. Attention is mainly given to the perception of gastro-enteritis. The research on which this article is based was concluded during 1984.

The article indicates that a majority of respondents maintains the view that aetiologically it is possible to distinguish between three categories of illness, viz. illness of sorcery, illness of the shades or ancestors and "natural" illness or illness that "just happens"

Within this general aetiological frame,

ious diarrhoeal disease of infants is

hally seen as sorcery related. Contact of infants with people regarded as ritually polluted is seen as a major causal agency. It is conceptualised as infants being "stepped upon" by "tracks". It causes an illness known as "phogwane", which can be interpreted as "sunken fontanelle". The concept "kokwana", which can be interpreted as "intestinal snake", is however also used to indicate serious diarrhoeal illness. In the case of

"kokwana" it is said that the snake, "sent" to the child through witchcraft, "eats" the child's food and the child itself.

Although many of the respondents were in doubt, the majority were of the opinion that Western doctors do not really understand the treatment of these dangerous illnesses.

The author believes that nursing practitioners who are involved in health education services should take note of these popular conceptions of gastroenteritis. Knowledge of these views should be used during education session in a meaningful way, to tactfully dissipate "misconceptions".

\section{Opsomming}

In hierdie artikel word 'n oorsig gegee van die kulturele voorstellinge aangaande diareesiektes onder babas soos dit deur Tswanasprekende stedelinge uitgedruk word. Klem word gelê op die voorstellinge en belewing van gastroënteritis. Die navorsing waarop die artikel gebaseer is, is in 1984 afgehandel.

In die artikel word aangetoon dat 'n meerderheid respondente etiologiese beskouinge handhaaf waarvolgens tussen drie kategorieë ongesteldhede onderskei word, $t w$. magiese of toorongesteldhede, ongesteldhede wat van die voorouerlike geeste afkomstig is en "natuurlike" ongesteldhede of ongesteldhede wat maar net gebeur.

Binne hierdie algemene raamwerk word ernstige diareesiektes van babas meestal gesien as magiese ongesteldhede. Die belangrikste oorsaak is kontak van babas met persone wat as ritueel onrein beskou word. Konseptueel vind dit uitdrukking daarin dat babas deur "spore getrap" word. Dit veroorsaak ' $n$ ongesteldheid bekend as "kokwana", wat met "ingewandslangetjie" vertaal kan word, word egter ook gebruik as etiket vir ernstige diareesiekte. In die geval van "kokwana" word gesê dat die slangetjie wat deur middel van 'n toorhandeling na 'n kind "gestuur" word, die kind se voedsel en die kind self "vreet".

Alhoewel daar by heelwal mense twyfel bestaan, is die meerderheid respondente tog van mening dat Westerse dokters nie ' $n$ goeie begrip van die behandeling van hierdie gevaarlike ongesteldhede het nie.

Die outeur is van mening dat verpleegkundiges wat by voorligtingsdienste betrokke is, kennis behoort te neem van hierdie populêre beskouinge oor gastroënteritis. Kennis van die beskouinge behoort sinvol by voorligtingsessies gebruik te word om op taktvolle wyse "wanopvattinge" te bekamp.

\section{INLEIDING}

In 'n onlangse artikel in Nursing $R S A$ Verpleging is die belangrikheid van die voorkoming en behandeling van diareesiektes onder veral kinders, uitgespei. ${ }^{1}$ In hierdie artikel wil die outeur enkele aspekte van hierdie belangrike oorsaak van mortaliteit onder kinders, soos deur Tswanasprekende stedelinge beleef, belig. Dit word gedoen vanuit 'n Antropologiese perspektief. Klem word geplaas op die populère voorstellings ten opsigte van veral die etiologie van diareesiektes, soos gevind tydens navorsing wat onder Tswanasprekende stedelinge in die vroeê tagtigerjare onderneem is. ${ }^{2}$

\section{OMSKRYWING VAN ENKELE} KONSEPTE EN UITGANGSPUNTE Soos uit die verwysing na "voorstelling" hierbo blyk, is siekte eintlik iets meer as biologiese of fisiologiese afwykings van "normale" parameters. Hierdie opvatting is onlangs weer sterk onder die aandag van verpleegkundiges gebring. ${ }^{3}$ Die hoofrede 
hiervoor is dat siekte nie slegs by geïsoleerde individue voorkom nie, maar by mense wat in 'n bepaalde sosiale en kulturele konteks lewe. Benewens die persoonlike belewing van ongesteldheid, is dit die sosio-kulturele konteks wat aan mense die sin en die betekenis van die werklikheid tot 'n baie groot hoogte aandui. Individue lewe dus binne die raamwerk van 'n sosiale struktuur waarin hulle in 'n newe- of bo- en ondergeskikte hoedanigheid teenoor verwante, vriende en vreemdelinge, asook kultuurbepaalde spesialiste verkeer. Dit verskaf die konteks waarvolgens 'n besondere toestand van ongesteldheid omskryf of ge-etiketteer sal word en wat medebepalend is in die optrede wat gevolg moet word om iets aan die toestand te doen of nie. Waar die hantering van die toestand moet plaasvind en wie dit moet onderneem, vind ook normaalweg binne die soșio-kulturele konteks plaas.

Met kulturele faktore word hier meer spesifiek verwys na die betekenisse wat mense in een of ander groepsverband aan die werklikheid heg. Dit hou dus verband met die probleem van die interpretasie van die werklikheid, die sg. kulturele tradisie. Met die oog op onderlinge begrip is dit in multikulturele Suid-Afrika belangrik om vertalings van die "tradisies" in interkulturele verstaanbare taal, wat nie etnosentries van aard is nie, weer te gee. Persepsies aangaande die werklikheid mag dus onderling verskil. Indien die moontlikheid nie erken word nie, kan dit aanleiding tot 'n kommunikasieprobleem gee. Uit die aard van die saak moet dit beklemtoon word dat die "feite" wat uit 'n etnografiese of kultuursbeskrywende perspektief weergegee word, dikwels net interpretasies van idees of interpretasies van interpretasies is.

\section{ETIOLOGIESE BESKOUINGE}

Ten aanvang word 'n aanduiding gegee van die oorsaaklikheidsraamwerk waarbinne 'n besondere groep verstedelike Tswanasprekendes siekte as onderdeel van algemene ongelukkigheid en ongesteldheid plaas. Dit kan genoem word dat hierdie raamwerk heel waarskynlik ook op ander groepe swart mense van toepassing is.

$\mathrm{Na}$ aanleiding van die trek van 'n ewekansige steekproef, kan met 'n redelike mate van sekerheid beweer word dat ongeveer ' $n$ driekwart van die ondervraagde respondente van mening was dat daar oorsaaklik gesproke, drie tipes ongesteldheid bestaan, tw.: Magiese (toor-) ongesteldhede (malwetse a boloi/meleko/ ditiro/batho); Ongesteldhede afkomstig van die voorouers (malwetse a badimo) Natuurlike ongesteldhede (malwetse a tholego/Modimo). Die skrywer het tydens informele gesprekke met Xhosasprekendes ook gevind dat soortgelyke kategorieë ongesteldheid onderskei kan word, tw.: Libulawo (as aanduiding van ' $n$ magies veroorsaakte aandoening); Zizinyanya (as aanduiding dat die ongesteldheid van die voorouers afkomstig is); Yindalo (as aanduiding dat die ongesteldheid "natuurlike" oorsake het).
Daar word dus onderskei tussen sg. "personalistiese" en "natuurlike" ongesteldhede, gesien vanuit die etiologiese hoek. Die woord "natuurlik", word hierbo egter in aanhalingstekens geplaas omdat ook dit wat as "natuurlik" beskou word, binne 'n kulturele konteks van betekenis gesien moet word. In dié verband kan na die redelik algemeen bekende verskynsel verwys word dat die sg. kiemteorie nie tradisioneel onder swart mense gehandhaaf is nie. Dit is natuurlik ook 'n relatief moderne teorie in die biomedisyne. Dit is bv. moontlik om die populêre siekte etiket Mookwana in Tswana direk met die Afrikaanse masels te vertaal. Onder Tswanasprekendes word dit oor die algemeen as 'n "natuurlike" siekte geklassifiseer. Oorsaaklik gesproke word die verskil in die betekenisinhoud wat aan masels geheg word in biomediese en populêre kontekse, egter duidelik uit die volgende aanhaling:

"My sister was about four years old when she was affected by a disease called measles. This disease, I was told, affects every child by nature ... This illness will not repeat itself, because, as I was told, the spots that were inside the body are now out and won't enter the body again." (Uittreksel uit 'n opstel van 'n swart matriekleerling, 1981 (2: 412-413).

Dit moet bygevoeg word dat die beeld van masels soos kortliks in die aanhaling uit die opstel geskets, redelik algemene aanhang in die dorpsgebied het. Daaruit is dit duidelik dat masels as 'n "natuurlike" (ke tholego $=$ dit is soos die wêreld geskep is) siekte beskou word. Oorsaaklik word daar egter 'n ander betekenis aan geheg as die biomediese. Die implisiete gelatenheid ten opsigte van die voorkoms van die siekte onder kinders wat uit die aanhaling uit die opstel blyk en die moontlike rol daarvan met verwysing na immunisering, is sover die skry wer weet, nog nooit nagevors nie.

Uit die navorsing het dit verder geblyk dat binne genoemde algemene etiologiese raamwerk, die respondente en segspersone wat ondervra is, tussen die volgende tipes siektes onderskei (let egter daarop dat die kategorieë wel oorvleuend van aard is):

Siektes wat verband het met die seisoene en seisoenwisseling (soos bv. verkoue en borsaandoenings).

Siektes wat net onder swart mense voorkom (soos bv. sejeso = "toorgif" wat veral volwassenes kan tref en phogwana = ingesonke fontanel, by babas).

"Ou" en "nuwe" siektes (dit is siektes wat onderskeidelik tradisioneel reeds bekend was aan die mense - soos bv masels en siektes wat met die koms van die witman bekend geword het -- soos tuberkulose).

Algemene siektes, dit is siektes wat onder beide wit en swart mense voorkom (met verkoue en masels as voorbeelde).

Uit bogenoemde data behoort dit ook deur te skemer dat die etiologiese raamwerk 'n belangrike rol kan speel indien die tussenkoms van 'n mediese spesialis verlang sou word. Indien 'n ongesteldheid beleef sou word, as sou dit van "personalistiese" oorsprong wees, sal die dienste van 'n tradisionele praktisyn (toordokter of kragdokter) aangewese wees. Dit geld hoofsaaklik vir siektes wat as siektes van swart mense beleef word. In die praktyk verloop dinge egter nie so eenvoudig nie. Mense se hoofdoel is om gesond te word en nie noodwendig om hulle etiologiese beskouinge te bevestig nie. In hulle soeke na terapie, kan dus wat Hammond-Tooke" as 'n "serial situational explanation" aandui, plaasvind. Dit wil sê die sieke en die belangrike persone rondom hom/haar, kan besluit dat hulle aanvanklike diagnose verkeerd was en hulle kan dus alternatiewe terapie gaan soek. Dit beteken terloops ook nie dat indien die tussenkoms van bv. 'n biomedikus geslaagd was nadat die behandeling van die toordokter misluk het, die betrokke pasiënt se denkraamwerk noodwendig sal verander nie.

Verder word bekende tekens en simptome ook nie altyd as enigste maatstaf gebruik om 'n spesifieke ongesteldheid binne die etiologiese raamwerk te plaas nie. Indien 'n ongesteldheid wat miskier1 andersins as van "natuurlike" oorsprong beskou sou word, deel van 'n reeks van ongelukkige gebeure is, kan dit subjektief as van "personalistiese" oorsprong beleef word.

Daar moet ook op gewys word dat daar nie noodwendig 'n eenvoudige verband tussen mense se oortuiginge en hulle optredes is nie. Persone mag bv. as gevolg van hulle posisie in 'n sosiale struktuur en in 'n poging om goeie verhoudinge te handhaaf of selfs uit nood, teen hulle "beterwete" of oortuiginge optree (2: 512 e.v.)

\section{DIE KLASSIFISERING VAN TOORONGESTELDHEDE}

Aangesien ernstige vorme van diareesiektes onder die betrokke segspersone dikwels oorsaaklik gesproke as magies van aard beskou word, word hier kortliks stilgest by 'n gedeelte van 'n taksonomiese nosologie van magiese of toorongesteldhede. Die taksonomie is bekom deur die intensiewe ondervraging van 'n Tswanasprekende toordokter. Dit kan genoem word dat aspekte van die taksonomie getoets is en dat daaruit geblyk het dat die meeste respondente (met presentasies wat van $63 \%$ tot $90 \%$ gewissel het) saam met die betrokke toordokter stem t.o.v. die basiese struktuur van die betrokke taksonomie (2: 226 e.v.)

Soos uit Tabel 1 afgelees kan word, kan twee hoofkategorieë toorongesteldhede onderskei word, t.w. dineelo en dibeela. Vrylik vertaal is dit onderskeidelik toordery wat gestuur is en toordery van 'n strik of lokval. In laasgenoemde geval word die middels wat die probleem veroorsaak geplaas naby plekke waar die slagoffer gewoonlik loop of ry. In die geval van "gestuurdes" word die middels in die rigting van die slagoffer geblaas, dit word in sy voedsel of drank geplaas of aan ' $n$ voorwerp gesmeer wat deur die slagoffer hanteer word 
TABEL 1

Taksonomie van Magiese- of Toorongesteldhede

TOORONGESTELDHEDE (BOTLHOKO BA MELEKO)

DINEELO (GESTUURDES)

DIBEELA (STRIKKE)

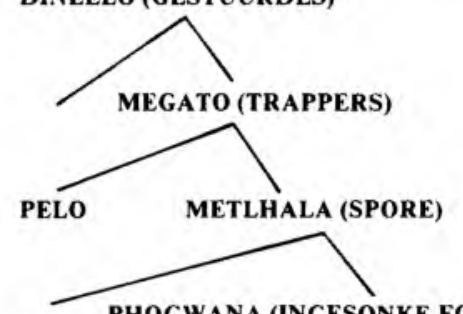

PHOGWANA (INGESONKE FONTANEL)/KOKWANA (INGEWANDSLANGETJIE)

\section{VOORSTELLINGE VAN \\ "METLHALA" (SPORE)}

Hierdie denkbeeld, as onderdeel van dineelo (gestuurdes), sluit toork wale in waarby middels nie noodwendig 'n rol beel nie. Hammond-Tooke verwys in die Sotho-verband daarna as "impersonal evil". Hy stel ook die hipotese, dat in vergelyking met die Nguni-volkere die Sotho klaarblyklik 'n obsessie met onreinheid (pollution) het. $\mathrm{Hy}$ is van mening dat dit moontlik daaraan toegeskryf kan word dat die Sotho sowel as Tswana in die verlede in groot nedersettings gekonsentreer was waar direkte beskuldigings van toordery sosiaal baie ontwrigtend kon wees (5: 124 e.v.). Indien hierdie hipotese aanvaarbaar is, dan is dit moontlik dat uit die aard van die moderne woongebiede, die situasie t.o.v. die Tswana nie juis verander het nie. Buurskap oorvleuel egter tot 'n mindere mate as in die verlede met verwantskap, met gevolglike meer intense kontak met vreemdelinge.

Dit moet beklemtoon word dat die segspersone in die dorpsgebied hierdie "rimpersonal evil" as toordery verwoord. vind plaas in die verband van toestande van onreinheid.

Hoewel in 'n mate subjektief beoordeel, kan beweer word dat die Tswanasprekende bewoners van die woongebied, naas sejeso (toorgif), 'n obsessie het oor megato ya metlhala (trappers van spore). Daarvolgens word phogwana (ingesonke fontanel) hoog aangeslaan as belangrike toorongesteldheid. Dit is juis 'n ongesteldheid wat van "spore" afkomstig is wat deur onbekende onrein persone in die omgewing gelaat is, hoewel dit ook moontlik is om byvoorbeeld 'n kind met voorbedagte rade te "trap". Comaroff skryf ook dat lede van die Tshidi-Rolong- stam, tydens haar studieverblyf teenoor haar opgemerk het dat openbare paaie plekke is waar mense $\mathrm{kwaad}$ versprei. Sy is van mening dat daarvoor historiese analogie te vinde is, en skryf ten opsigte van die tradisionele nedersetting:

"Social responsibility in a Tswana town seems to have dictated that the public byways be avoided by people likely to lay down tracks, and that they be kept rigidly apart from others to whom their polluting contact could mean death: new-born babies, young children, the sick, and cattle and small stock" (6: 37). Hierdie denkbeelde soos deur Comaroff verwoord, kom ook in die dorpsgebied voor. 'n Bejaarde man van 70 jaar en lidmaat van een van die Afrikaanse sendingkerke, wat reeds sedert 1937 'n dorpenaar is, het tydens 'n gesprek wat oor phogwana gehandel het, teenoor die navorser opgemerk dat hy van mening is dat die dorpsmense te naby mekaar woon. Hy het daarna verwys dat daar te veel mense is wat in mokhukhu's (sinkhutte in agterplase) woon en verklaar dat hulle dikwels sterk middels by hulle dra. Hulle stap dan verby die huis na die agterplaas waar die mokhukhu is en dan kry die kinders dit soos 'n "gas" in. Dit maak die kinders ongesteld.

Die vrees dat kinders "getrap" kan word kan waarskynlik as 'n belangrike rede beskou word waarom die mense in die woongebied steeds 'n moeder en kind vir minstens 10-dae na die geboorte van 'n kind, afsonder. Inderwaarheid, word die baba inderdaard gewoonlik vir 'n nog langer tydperk afgesonder as die moeder. Selfs mense wat skepties staan teenoor die tradisionele etiologiese beskouinge volg die praktyk, hoewel die motivering daarvoor mag verskil. Dit mag byvoorbeeld gedoen word om sosiale koste te bespaar. So het ' segsman aan die navorser gesê dat sy vrou en kinders wel na die geboorte afgesonder is, maar dit is net gedoen om die "ou vrou" (verwysende na sy skoonmoeder) wat steeds glo dat kinders "getrap" kan word, tevrede te stel. Die opmerkings is deur sy vrou bevestig.

'n Ses en twintigjarige man met wie die navorser-goed bevriend was, wat st. 8 geslaag het, klerklike werk doen en getroue lid van 'n nie-Ortodokse Kerk Geassosieer met Blankes is, se optrede is moontlik tekenend van die situasie. In gesprekke het hy die navorser onder die indruk gebring dat hy skepties staan teenoor die tradisionele etiologiese raamwerk. Tydens die studietydperk het hy egter die trotse vader van 'n babadogter geword. Toe hy op 'n roetine grondslag genader is oor 'n skedule wat hy as navorsingsassistent moes voltooi, het hy die navorser meegedeel dat hy die skedule die vorige dag wou voltooi.
Hy het dit egter nie gedoen nie aangesien sy baba ongesteld is. Dit was 'n ongesteldheid wat met diaree (letshollo) gepaard gegaan het. Hy het bygevoeg dat hy voel dat hy dadelik na werk moes huistoe gaan en nie baie rondloop nie, veral nie in die aand nie, aangesien dit sleg vir die kind kan wees. Hy is van mening dat 'n mens dan maklik op allerhande "spore" kan trap en dit kan die kind se toestand dalk vererger. Hy is toe gevra of hy weet dat 'n tradisionele praktisyn 'n kind se phogwana kan "versterk", waarop hy bevestigend geantwoord het, maar bygevoeg het dat sy kerk (Die Ou Apostoliese Kerk, of soos dit populêr bekend is "Die Broer en Suster Kerk") sodanige besoeke verbied. Hy is gevra of hy nie bekommerd is omdat sy kind nie "versterk" is nie, waarop hy geantwoord het: "Ja, ons is. Dit is daarom dat my vrou nie met die kind rondloop nie, behalwe Sondae, kerk toe en terug".

Die segsman se vrou, 'n onderwyseres, kom ook die gebruik na om haarself eers 'n bietjie uit te melk as sy van die skool af kom, aangesien die melk andersins "warm" is, en die kind ongesteld kan raak as sy dadelik geborsvoed word. Tydens die ongesteldheid het die moeder die kind na 'n Westerse praktisyn geneem. Die vader het die medisyne wat deur die dokter verskaf is egter eers na een van die Oudstes in die kerk geneem, soos dit gebruiklik in die besondere kerk is, om die medisyne te seên.

Ten opsigte van hierdie denkbeeld dat kinders "getrap" kan word, het 'n 48-jarige vrou ook teenoor die navorser opgemerk:

"In die vroeë tyd kon mens weier dat ander mense (by 'n baba) inkom. Vandag is mens 'n Christen en jy moet sê: ' Ja, jy kan maar kom kyk'. Dit is waar die fout inkom."

Hoewel die idee dat 'n kind "getrap" kan word, as 'n belangrike rede beskou kan word waarom 'n kind afgesonder moet word, is die afsondering nie in alle gevalle ewe streng nie. Die navorser self is egter by 'n paar geleenthede versoek om eers ' $n$ bietjie buite 'n huis waar 'n baba is te sit, voordat hy kon ingaan. Hy is meegedeel dat sy voete eers moet "afkoel".

Twintig segspersone uit die huishoudings wat gereeld deur die navorser besoek is en uitgevra is oor die toestande waardeur 'n kind "getrap" kan word, het meestal min of meer dieselfde antwoorde verskaf. 'n Vroulike respondent het byvoorbeeld die volgende lys van toestande verskaf:

- Vroue wat 'n miskraam gehad het.

- Vroue wat in die beginstadium van swangerskap verkeer.

- Vroue wat 'n promiskue lewe lei

- Mense wat met sterk (magiese) middels rondloop.

- Vroue wat menstrueer.

- Mense wat van 'n begrafnis afkom.

- 'n Man wat te gou omgang met sy vrou het na die geboorte van 'n kind (volgens haar moet die man 3 maande wag).

- "Warm melk". (As die moeder weg was, moet sy eers 'n rukkie wag of haarself uitmelk, voordat die suigeling mag drink.) 
- "Vuil melk". ('n Moeder of vader wat, terwyl 'n suigeling nog geborsvoed word, ook met ander mans of vroue seksuele omgang het, sal tot gevolg hê dat die suigeling "vuil melk" inkry.)

- Sy het bygevoeg dat daar oor die algemeen nie baie mense by 'n huis toegelaat moet word terwyl 'n kind nog klein is nie.

Benewens die feit dat daar van mense wat byvoorbeeld van die werk af kom, verwag word om eers ' $n$ tydjie buite te wag alvorens hulle 'n huis met 'n suigeling binnegaan, sê van die segspersone ook dat 'n mens jou hande en voete kan "afkoel" deur jou hande met as (molora) te vryf, of deur 'n bietjie as in jou skoene te sit. Daar is ook andere wat sê dat 'n mens as voor die ingang van 'n huis waar 'n kranke is, kan strooi.

\section{KOK WANA EN PHOGWANA}

Soos uit Tabel 1 afgelei kan word, kan kokwana/phogwana as belangrike ongesteldhede beskou word wat die gevolg van die "trap" van 'n kind kan wees. Daar is egter respondente en segspersone wat dit anders as die praktisynsegsman, as twee afsonderlike ongesteldhede beskou.

Volgens die praktisynsegsman, is phogwana slegs 'n teken (sekao) van die teenwoordigheid van kokwana. Kokwana kan volgens hom deur "spore" sowel as die stuur van middels veroorsaak word. In sy beskouing dat dit nie twee afsonderlike ongesteldhede is nie, word hy nie deur die meerderheid respondente wat daaroor gevra is, gesteun nie. Van die $\mathbf{3 0}$ respondente wat ondervra is, het $17(57 \%)$ gesê dat dit twee afsonderlike

ongesteldhede is, terwyl $12(40 \%)$ gesê het dat dit maar dieselfde ongesteldheid is. Toe die segsman met hierdie feit gekonfronteer is, het hy egter baie beslis sy standpunt bly handhaaf. Hy het gesê dat hy in sy praktyk as sangoma (tradisionele praktisyn) nog nooit 'n geval van phogwana teengekom het, waar die onderliggende oorsaak nie die teenwoordigheid van kokwana was nie. Hy onderskei egter wel twee soorte kokwana, te wete 'n tipe wat met "spore" verband het en volgens hom gekenmerk word deur 'n silwergrys kleur. Dit het volgens hom die lengte en deursnee van 'n nuwe potlood. $\mathrm{Hy}$, asook ander segspersone met wie oor die onderwerp gesels is, beskryf dit ook as "mooi" en blink van voorkoms. Die kokwana wat egter direk deur middels gestuur word, se belangrikste kenmerk in onderskeiding van die ander tipe, is dat dit twee rooierige koppe het wat aan weerskante van die lyf sit. Dit word ook as gevaarliker as die ander tipe beskou. Laasgenoemde tipe word kokwana ya matabele genoem, teenoor kokwana ya basotho. Dit word dan ook gesê dat dit die "Zulumense" is wat die tweekoppige "ingewandslangetjie" aan die Tswanamense bekend gestel het.

Hoewel die navorser nie werklik oor gegewens beskik om 'n saak daarvoor uit te maak nie, onder meer omdat daar in die literatuur wat geraadpleeg is slegs in 'n onlangse publikasie bykans terloops na kokwana verwys word as "inflammasie van die maag" (6: 28), is dit wel moontlik dat die verskil van mening oor die ongesteldheid daaraan toegeskryf kan word dat dit nie 'n tradisionele Tswanakonsep is nie. Die wisselvorm nogana (slangetjie), word wel ook gebruik om daarna te verwys. Kriel maak ook melding daarvan dat disenterie onder die Noord-Sotho as noga e khwibidu bekend staan. ${ }^{8}$ Dit sou letterlik as die "slang van die rooi of bloederige stoelgang" vertaal kon word.

Segsliede wat phogwana as 'n afsonderlike ongesteldheid beskou, konseptualiseer dit dikwels as 'n ongesteldheid van 'n kind se hoof. Andere is van mening dat dit die "ingewandslangetjie" kokwana is, wat nadat dit aan die kind se ingewande "gevreet" het, ook na die kind se kop beweeg om sodoende die fontanel te laat insak.

In 'n poging om vas te stel tot welke mate die denkbeeld van phogwana as 'n afsonderlike ongesteldheid of net as 'n teken van 'n ongesteldheid gesien word, is respondente daarna gevra, maar sonder enige verwysing na kokwana. Uit die respons het dit geblyk dat 'n betekenisvolle meerderheid respondente dit wel as 'n afsonderlike ongesteldheid beskou, te wete $22(73 \%)$. Ses $(20 \%)$ het gesê dat dit slegs 'n teken van ongesteldheid is, terwyl $2(7 \%)$ geantwoord het dat hulle nie weet nie.

Soos reeds terloops hierbo vermeld, word phogwana ook as 'n ongesteldheid beskou wat Westerse medici nie goed verstaan nie. Dit is 'n ongesteldheid wat baie van die segsliede meen, tipies van swartmense is. In 'n direkte vraag aan respondente in 'n klein ewekansige steekproef of Westerse dokters phogwana en kokwana goed verstaan, was die respons soos volg:

PHOGWANA: Ja: 7 (23\%); Nee: 22 (73\%); Weet nie: $1(3 \%)$.

KOKWANA: Ja: 6 (20\%); Nee: 23 (77\%); Weet nie: 1 (3\%).

In antwoord op 'n oop vraag aan 30 lede van huishoudings om enige ongesteldhede te noem wat hulle reken Westerse dokters nie verstaan nie, het 13 ook na phogwana verwys en 2 na kokwana. Een van hierdie segspersone was egter wel die mening toegedaan dat blomedici van Indiër herkoms hierdie ongesteldhede goed verstaan. 'n Een en vyftigjarige vrou wat gesê het dat Westerse dokters nie ongesteldhede soos sejeso, phogwana en kokwana verstaan nie, het bygevoeg:

"Die dokters sal net sè die siekte is 'informasie' (inflammasie?) of appelkoosmaag, dit is al wat hulle verstaan."

'n Bejaarde vrou van 72 jaar het beweer dat sy al baie gesien het dat Westerse dokters die ongesteldhede nie kan "regkry" nie. Sy sê dat indien die phogwana (fontanel) nog nie ingeval (go wela) het nie, hulle dit miskien sal "regkry", maar as die phogwana reeds net 'n bietjie ingeval het, sal hulle sukkel. Sy het bygevoeg dat ' $n$ tradisionele praktisyn dit wel sal "regkry". 'n Ander vrou se kommentaar was dat sy ook gehoor het dat Westerse dokters dit nie kan "regkry" nie. Sy het bygevoeg dat indien so 'n kind deur die dokter hospitaal toe gestuur word, sê die mense: "Nee, gaan haal hom uit dat die ngaka ya setswana (Tswanadokter) hom kan help".

'n Dertigjare vrou het die navorser meegedeel dat sy 2 kinders as gevolg van kokwana verloor het. Sy sê dat hulle net ouer as 'n jaar was. Sy het hulle na die hospitaal geneem en hulle het beter geword. Sy het egter bygevoeg dat "die Witmense dit nie maklik sien nie" en na die kinders se ontslag uit die hospitaal het die ongesteldheid weer begin. Sy sê sy het die kinders daarna na 'n sangoma geneem, maar hy kon haar nie help nie. Dit was te laat. Sy het die ongesteldheid nie "gou genoeg gesien nie".

Onder die segspersone wat van mening is dat Westerse dokters wel phogwana verstaan, het 'n vrou van 48 , byvoorbeeld gesê dat sy nie glo dat daar 'n

ongesteldheid is wat hulle nie verstaan nie, omdat hulle baie slim is. Sy het voorts daarop gewys dat phogwana tot gevolg het dat 'n kind se maag baie werk en dan gee hulle die kind water ("drip") wat verhoed dat die kind maklik doodgaan. Die verwysing na "water wat in die kind se kop ingesit word" (binneaarse oorgieting), me klaarblyklike goeie gevolge in gevalle van phogwana, is ook by ander segspersone aangetref.

Benewens die feit dat daar mense is wat positief is teenoor Westerse geneeskundige doeltreffendheid in die geval van

phogwana, was segspersone wat daaroor gevra is, meestal van mening dat tradisionele praktisyne en profete, wel hierdie ongesteldheid kan genees. Enkeles was egter ook skepties hieroor en sê dat dit nie almal van hulle is wat daartoe instaat is nie, maar dat net die ou praktisyns dit kan doen.

'n Swart matrikulant wat in 1981 aan 'n opstelwedstryd deelgeneem het waarin hulle oor siektes tuis moes skryf en volgens die biografiese besonderhede wat sy verskaf het op daardie stadium 18 jaar oud was, het die volgende beskrywing van kokwana in haar opstel gegee:

"My baby sister who at present is three years old, had at one time made us worr My mother had to leave her after she was three months old, because they are only given that much time maternity leave. She was worried because there was nobody to look after the baby. Fortunately there was an old lady who was prepared to look after her.

"After hardly a month I noticed that something was wrong with our little Bongi. I told my mother that the baby was losing weight, but she told me I was being to talkative and that the only trouble was that the baby was not drinking from her regularly as she was used to while she was not at work. But she became leaner and she was not as active as she used to be. My mother now also realised that something was wrong with her.

"In the meantime her nurse also saw that the baby's eyes were red and sleepy. She took her to the traditional doctor without our knowledge, as she was responsible for her during my mother's absence. That doctor told her that the baby had been bewitched. He said that the baby was suffering from kokwana. This kokwana is 
a worm with two heads. We did not know how it had entered her. The doctor gave the old lady a herbal medicine to cook and to give it to the child with milk.

"From the start I was against the idea of taking the baby to the traditional doctor, because I knew that they were good during the days of our forefathers but not today's generation. The old lady believed too much in the traditional doctors and she told us that after a week Bongi will be fit ... But after that weekend she was even worse than before.

"Mother then decided to take her to the medical doctor. The doctor told her that the baby was suffering from dehydration. He said that the baby's head was not as round as it should be and the anus red as the result of a running tummy and because she vomited a lot. He said that there is no such a thing as kokwana which had bitten the baby's anus. The trouble was that the baby had lost a lot of water. He sent her to hospital immediately. After she had been discharged from hospital, the doctor instructed us to give the baby as much ater as possible."

Soos by implikasie uit die gevallestudie blyk, is daar waarskynlik 'n verband tussen 'n ongesteldheid soos kokwana en ongesteldhede wat met diaree by babas gepaard gaan. Uit gesprekke met Swart verpleegkundiges by die plaaslike kliniek, is die vermoede dat phogwana en kokwana veral met die biomediese konsep gastroënteritis ooreenstem, bevestig (vgl. ook 9: 224). Dat gastroênteritis 'n belangrike oorsaak van sterftes onder kinders in die woongebied is, word deur inwoners van die dorpsgebied besef.

Segspersone se "bewustheid" hiervan, blyk daaruit dat hulle byvoorbeeld phogwana as 'n belangrike toorongesteldheid uitsonder. In dié verband het 'n 37-jarige man aan die navorser gevra of witkinders nie ook die ongesteldheid opdoen nie. Hy het sy vraag dadelik opgevolg deur te sê dat daar mense is wat sê dit is sommer 'n ou geloof. Die kinders, sê hy, het egter bly sterf. Dit het mense weer na die dingaka

(tradisionele praktisyns) laat gaan.

Segsliede wat die gedagte dat phogwana deur toordery veroorsaak word, verwerp, plaas dit ook nie noodwendig binne die raamwerk van die biomediese denkbeeld van 'n diareesiekte nie, alhoewel dit met diaree as teken daarvan verband het. Soos reeds aangedui, word phogwana dikwels deur mense gesien as 'n ongesteldheid wat eintlik in 'n kind se kop gesetel is. Op 'n vraag aan 'n respondent wat die tradisionele etiologiese raamwerk verwerp, of dit ' $n$ ongesteldheid van ' $n$ kind se kop is, was sy antwoord: "Ons 'vat' dit so, daar gebeur iets in die kind se kop". Op 'n vraag aan 30 respondente in 'n klein ewekansige steekproef, of phogwana meestal 'n soort ongesteldheid van 'n kind se kop is het 29 uit die $30(97 \%)$ bevestigend geantwoord. Daarteenoor het 27 uit $30(90 \%)$ op die vraag of kokwana 'n ongesteldheid van 'n kind se ingewande is, bevestigend geantwoord.

Dit mag wees dat die waarneming dat die hospitaalbehandeling van kinders wat aan die ongesteldheid ly, geskied deur die toediening van ' $n$ binne-aarse oorgieting in die hoof van 'n baba, die Tswanabeskouing dat dit 'n "kopongesteldheid" is, versterk.

Dit is moontlik ook vermeldingswaardig dat die sienswyse dat ' $n$ ingesonke fontanel as ' $n$ afsonderlike ongesteldheid beskou moet word, elders in die wêreld voorkom. In Honduras word dit byvoorbeeld ook as 'n ongesteldheid van 'n baba se kop beskou (10: 355-356).

In ander gevalle word egter veel nader aan die biomediese konsep beweeg. Ten opsigte van kokwana, het 'n man van ongeveer 45 jaar en wat die bestaan daarvan ontken, gesê dat dit seker maar 'n soort van diaree (letshollo) is. Daarop het sy vrou bygevoeg dat dit "gastro" is en deur vuil kos en bottels veroorsaak word. Die opmerking van sy vrou, het die man laat byvoeg dat toe hy vir ' $n$ versekeringsmaatskappy gewerk het, "hy baie kinders so begrawe het, gewoonlik uit vuil huise". Hy het verder gesê dat 'n mens die ongesteldheid nie by "spoggerige" mense aantref nie.

\section{TEKENS EN SIMPTOME: POPULERE OPVATTINGE}

Uit onderhoude met spesialiste

(tradisionele praktisyns) en nie-spesialiste, kon die volgende saamgestelde beeld van die belangrikste konstellasie van tekens en simptome van kokwana en phogwana soos die respondente dit self sien, verkry word:
Hieruit blyk dit dat dit moeilik sal wees om bloot net simptomaties tussen die twee ongesteldhede te onderskei. 'n Paar segspersone het egter spesifiek daarna verwys dat in die geval van phogwana. 'n kind se stoelgang 'n groen kleur sal hè. In die geval van kokwana word die rooi en droë neus, mond en anus, deur die segspersone geïnterpreteer as 'n aanduiding daarvan dat die kokwana die kind so "vreet". Dit is ook tekens van die ongesteldheid wat hierbo in die aanhaling uit die opstel vermeld is. Die rooi irritasie en die groen stoelgang is blykbaar ook vir die segspersone 'n teken dat dit nie gewone diaree, soos wanneer ' $n$ kind besig is om tande te kry (go medisa), is nie. In die geval van "tandediaree" sal die stoelgang ook geel wees en nie groen nie. Daarby sal die kind in laasgenoemde geval ook geneig wees om sy handjies te kou en nie om sy neus te vryf nie.

Van die segspersone sê ook dat wanneer die kokwana 'n kind klaar binne "gevreet" het, gaan die anus (sebono) vanself oop en dit is asof die voedsel wat die kind eet sommer onder uitloop. Verder word gesê dat kokwana veral van mense hou wat baie melk drink. Die "slangetjie" eet dit en word dan lekker vet, word gesê. Hulle sê ook dat indien 'n kind kokwana het, moet die kind nie vleis, melk of vetterige kos gegee word nie. Dit maak die kokwana net sterker. So 'n kind moet net swart tee kry om te drink.

Volgens segsliede is dit moeilik om kokwana dood te kry. Indien aan so 'n persoon medisyne gegee word, sal die kokwana sy kop wegsteek. Hulle sê dat dit om hierdie rede ook nodig is om in die geval waar kokwana 2 koppe het, ook 'n enema (of soos dit algemeen in die dorpsgebied bekend staan, sepeite), toe te dien. Op die manier kan altwee die koppe bygekom word. Die erns van kokwana as ongesteldheid, blyk ook duidelik uit die woorde van 'n vroulike respondent:

“... (Dit) is 'n gevaarlike ding. Dit eet die kind by sy gaatjie (anus) dat dit sommer so rooi is en ook by die mond. Hy word rooi-rooi en is seer, orals. As jy aan die kind vat dan huil hy. Dit het die kind vrot gemaak, (want) dit eet hom mos".

Dat die fontanel as ' $n$ belangrike deel van 'n kind se anatomie beskou word, blyk ook daaruit dat ' $n$ vrou dit beskryf as "ons skaal", na analogie van die skaal wat by die kliniek gebruik word om babas se vordering te bepaal. By navraag, het dit ook geblyk dat sommige segspersone die klop van die fontanel met die hartklop assosieer, terwyl ander van mening is dat dit onafhanklik funksioneer.

Die verwysing na groen gekleurde diaree in die geval van phogwana, is ook insiggewend. Dit is 'n verskynsel van Loudon met verwysing na die Zulu beskryf, hoewel in ' $n$ ander verband. Hy skryf dat die Zulu die idee van 'n aangebore ongesteldheid wat as isiGwebe bekend staan, het:

"The visible sign of isiGwebe is the meconium, a greenish-coloured material excreted by all newborn infants before they have taken sufficient nourishment to start producing the normal, bright yellow 
faeces. It is possible that there is also an association in the minds of Zulu women between the green meconium and the greenish slimy faeces characteristic of infantile gastroenteritis and infant malnutrition. The first is a sign of congenital evil, and the second is a frequent precursor to the death of children" (11:358).

In die dorpsgebied word 'n soortgelyke beskouing aangetref en wel in die sin dat vroue die groen mekonium van pasgebore babas, as 'n aanduiding daarvan sien dat die suigelinge se naweltjie (khujwana) nog nie na die geboorte inwendig "genees" is nie. By navraag het segspersone dan ook die verband gelê tussen die groen fekus van die pasgeborenes en in gevalle van phogwana. Hulle erken dus eintlik dat dit op 'n ingewandsongesteldheid dui.

\section{SLOT}

Die outeur is die mening toegedaan dat verpleegkundiges wat betrokke is by voorligtingsdienste aan swart moeders, moontlik nie genoeg kennis dra en/of kennis neem van populère opvattinge oor die oorsake van ongesteldhede nie. In die oordra van kennis is die beweging van die bekende na die onbekende seker steeds 'n gesonde opvoedkundige beginsel. Daar behoort ' $n$ sinvolle integrasie van populêre opvattinge met Westerse mediese kennis in voorligting te wees. Die taktvolle uitlig van "wanopvattinge" in die populêre sektor, kan dan moontlik met vrug aangewend word in die stryd om die diareesiektes, wat as ' $n$ massamoordenaar beskou kan word, te help bekamp.

\section{VER WYSINGS}

1. Desai, F. 1987. Diarrhoeal disease and its management. Nursing RSA Verpleging. Maart, vol. 2, no. 3: 21-23.

2. Booyens, J.H. 1984. Etnomedisyne onder Tswanasprekende stedelinge. (Ongepubl. D.Phil-proefskrif - P.U. vir C.H.O.)

3. De Klerk, G. 1987. Siekte vanuit sosialewetenskaplike perspektief. Curationis. vol. 10, no. 1:17-21.

4. Hammond-Tooke, W.D. 1970. Urbanization and the interpretation of misfortune. Africa. vol. 40: 38.

5. Hammond-Tooke, W.D. 1981. Patrolling the herms-social structure, cosmology and pollution concepts in South Africa. Johannesburg, Witwatersrand U.P.

6. Comaroff, J. 1974. Baralong cosmology - a study of religious Pluralism in a Tswana Chiefdom. (D.Phil-proefskrif - University of London.) (Mikrofiche)

7. Daneel, M.H. et al. 1984. Some perceptions of disease among the urban Blacks in Mangaung, Bloemfontein, South Africa (Ongepubl. voordrag Conference on African Healing Strategies, Florida, U.S.A.).

8. Kriel, T.J. 1958. The new English-Sesotho dictionary. Johannesburg, APB.
9. Ulin, P.R. 1979. The traditional healer of Botswana in a changing society. Ademuwagun, Z.A. et al (reds.) African therapeutic systems. Massachusetts, Crossroads.

10. Kendall et al. 1983. Anthropology, communications, and health - the mass media and health practice program in Honduras. Human organization. vol. 42, no. 4: 353-356.

11. Loudon, J. B. 1959. Psychogenic disorder and social conflict among the Zulu. Opler, M.K. (red.) Culture and mental health. New York, Macmillan.

\section{ERKENNING}

Die finansiële ondersteuning van die Raad vir Geesteswetenskaplike Navorsing by die uitvoering van hierdie navorsing word met dank erken. Die standpunte en bevindinge in hierdie artikel uitgespreek verteenwoordig nie noodwendig die oordeel van die Raad nie. Dr. C. L. Ferreira, Dept. Verpleegkunde UPE, word bedank vir sinvolle kommentaar op ' $n$ voorlopige weergawe van die artikel.

$$
\begin{gathered}
\text { J.H. Booyens } \\
\text { Senior Lektor } \\
\text { Departement Volkekunde } \\
\text { UPE }
\end{gathered}
$$

